\title{
МОДЕЛЮВАННЯ СТРЕСОВОЇ СИТУАЦЇ̈ ЛЮДИНИ В АВТОМАТИЗОВАНИХ СИСТЕМАХ УПРАВЛІННЯ ТЕХНОЛОГІЧНИМИ ПРОЦЕСАМИ
}

\begin{abstract}
Проаналізовано причини виникнення та впливу на організм і поведінку людей стресу під час управління технологічними процесами. Актуальність виконаного дослідження полягає в тому, що сучасна особистість перебуває під впливом великої кількості стрес-чинників. Щоденні стреси викликають у людини потреба долати різноманітні скрутні життєві обставини. Внаслідок цього особистість використовує особливий тип поведінки - долаючий, який спрямований на подолання життєвих труднощів різного рівня. Обгрунтовано актуальність вивчення проблеми долаючої поведінки фахівців, пов'язаних із технологічними процесами. Показано, що особливої уваги потребує питання ресурсів, що дають змогу продуктивно долати стрес та зберігати психоемоційне здоров'я особистості. Визначено проблемні питання, що потребують подальшого вивчення та вирішення. Вказано на потребу оформлення окремої галузі "стресології" як цілісної системи вивчення та управління стресчинниками, тобто обставинами, які спричиняють стресовий стан. На основі здійснених спостережень досліджено ймовірну модель тривалості перебування та виходу людини з екстремальної ситуації. Також було досліджено взаємозв'язок рівнів працездатності з психологічним та емоційним станом людини. Проаналізовано вияв стресу як неспецифічної реакції організму у відповідь на несподівану та напружену ситуацію. При цьому джерелами стресу виступають як зовнішні, так і внутрішні чинники. Основну увагу зосереджено на наслідках, причинах та етапах розгортання стресу, а також чинниках, що сприяють його подоланню. На основі дослідження виконано порівняльну характеристику тенденцій стресостійкості людини до зовнішніх подразників в умовах витривалості. Наведено результати дослідження стрес-долаючої поведінки 3 урахуванням різних видів стресів, основну увагу зосереджено на виробничих стресах. Реакції людей розподілено на дві великі групи: фізіологічні і психологічні. Запропоновано підхід, який буде досить дієвий під час набору кадрів, оскільки стресостійкість людей у деяких професіях відіграє значну роль в ефективності виконання поставлених завдань та дасть змогу визначати людей, неспроможних працювати в певних умовах вже на початкових етапах роботи. Перспективою подальшого дослідження $\epsilon$ визначення основних чинників, що впливають на ефективність стрес-долаючої поведінки людини залежно від ступеня навантаженості.
\end{abstract}

Ключові слова: стресор, стрес, стресорна реакція, стресогенні зміни, моделювання.

Вступ. Дослідження особливостей поведінки людини у стресових ситуаціях завжди були у центрі уваги науковців. До сьогодні було виконано велику кількість емпіричних досліджень окремих аспектів стресу, складних життевих ситуацій. Однак, незважаючи на поширеність виявлення стресу в повсякденному житті, багато аспектів залишаються недостатньо висвітленими. Зокрема, зарубіжні дослідження стресу і шляхів його подолання недостатньо актуальні для реалій сучасної України, використовуючи обчислювальні системи високої продуктивності $[2,5,6]$.

У сфері охорони праці існує завдання - зберегти життя і здоров'я людини в процесі трудової діяльності [3]. Досягти виконання цієї вимоги можливо тільки в разі зменшення шкідливого впливу на людину різноманітних чинників навколишнього середовища. Загалом за своїм походженням ці чинники поділяються на виробничі, побутові, соціальні, економічні, політичні, кліматичні, екологічні [13]. Їхній вплив може здійснювати- ся як поза виробництвом (коли працівник $\epsilon$ приватною особою), так і на виробництві під час виконання трудових обов'язків (тоді він $€$ працівником підприємства, установи, організації, закладу). Проте навіть позавиробничі чинники можуть впливати на працівника, котрий може "перенести" їх на підприємство - стосовно себе чи довколишніх людей.

Окремий або сукупний вплив зазначених чинників може спричинити виникнення такого специфічного стану організму, як стрес $[1,7,9]$. Канадський патолог Ганс Сельє, автор концепції і терміна "стрес", у 1936 р. визначив його як неспецифічну нейрогормональну реакцію організму на будь-яку пред'явлену йому вимогу. При цьому в організмі виникають однотипні біохімічні зміни, спрямовані на подолання впливу шкідливих чинників шляхом адаптації організму до пред'явлених вимог. Чинники, що спричиняли стан стресу, Г. Сельє назвав стресорами, а сукупність змін в організмі під впливом стресорів - адаптаційним синдромом. Амери-

\section{Інформація про авторів:}

Мочурад Леся Ігорівна, канд. техн. наук, ст. викладач, кафедра систем штучного інтелекту. Email: lesiamochurad@gmail.com

Бойко Наталя Іванівна, канд. екон. наук, доцент, кафедра систем штучного інтелекту. Email: nataliya.i.boyko@lpnu.ua

Яцків Марія Володимирівна, студент, кафедра систем штучного інтелекту. Email: mikamause99@gmail.com

Цитування за ДстУ: Мочурад Л. І., Бойко Н. І., Яцків М. В. Моделювання стресової ситуації людини в автоматизованих системах управління технологічними процесами. Науковий вісник НЛТУ України. 2020, т. 30, № 1. С. 152-157.

Citation APA: Mochurad, L. I., Boyko, N. I., \& Yatskiv, M. V. (2020). Modelling of human stress situation in automated control systems of technological processes. Scientific Bulletin of UNFU, 30(1), 152-157. https://doi.org/10.36930/40300126 
канський фізіолог Уолтер Бредфорд Кеннон для всіх фізичних, хімічних, емоціональних подразників, що призводять до порушення рівноваги у внутрішньому середовищі організму, дав визначення "загальний адаптаційний синдром". Тому, через необмеженість впливу стресорів, можливість стресу на виробництві існує повсюдно ("стресогенні ситуації"), а відповідно, й похідні від нього негативні впливи на здоров'я працівників ("стресорні реакції") $[4,8,11]$.

Об'єктом дослідження стали людина-оператор та характер ії поведінки в момент інформаційного "удару" появи такої ситуації, яка потребує негайної реакції.

Предметом дослідження є показники стану організму людини-оператора, зокрема: тиск систолічний, тиск діастолічний, пульс, температура тіла та їхнє співвідношення до відповідних норм.

Мета дослідження - визначити особливості реакції людини-оператора в певні моменти часу на подразники відповідно до професійного спрямування, дослідження стресу як стану психічного напруження, що виникає у процесі діяльності людини у повсякденному житті.

Методи та об'єкт дослідження. В основу методології дослідження та моделювання виходу зі стану перенапруження покладено метод протиставлення, за якого вимірювана й еталонна величини одночасно впливають на об'єкт дослідження, а також допоміжні методи побудови моделі тривалості перебування оператора в екстремальній ситуації на основі декомпозиції імпульсу.

Під час дослідження наявних аналогів виявили апаратурний комплекс "Вектор 01.1" - індикатор емоційного напруження людини. Цей комплекс складається із трьох блоків та приєднаного до них комп'ютера, що сортує отримані дані за прізвищем та вивантажує звіт у форматі Excel. Також проаналізували роботу біомедичної системи МІС - ДЕС, яка базується на даних, отриманих внаслідок шкірно-гальванічної реакції та різних психологічних методик. До недоліків цієї системи можна віднести складність та високу затратність в отриманні даних, через що її використовують тільки в діагностичних центрах та санаторно-курортних установах.

Отже, на сьогодні неможливо підібрати такого програмного засобу чи комплексу, який моделював би поведінку людини на основі зібраних та проаналізованих даних показників стану організму людини-оператора. Особливо актуально ця проблема постає в завданнях із прийняття важливих рішень різних професійних спрямувань. Тому первинним завданням $\epsilon$ аналіз виміряних показників оператора та їх порівняльна характеристика 3 еталонним показником. Під час аналізу потрібно здійснити побудову тренду у вигляді часових рядів, що надалі дасть змогу дослідити стресостійкість оператора протягом робочої зміни. На основі отриманих результатів сформували відповідне зіставлення реакції оператора на певний вид подразника.

Аналіз літературних джерел. Уперше питання стресу, якому піддаються працівники, було порушено в 1966 р. у доповіді, підготовленій Національним консультативним комітетом з питань гігієни навколишнього середовища для Головного лікаря Сполучених Штатів Америки. Зокрема, в документі відзначено, що працівники дедалі частіше відчувають на робочих місцях психологічний стрес [2]. Проте тільки з початку 1990-х років розпочався активний розвиток досліджень шкід- ливого впливу стресу на здоров'я працівників (Європейський фонд удосконалення життя і праці (1992) у Голландії [6], США [3], страхова компанія "Сент-Пол Файр енд Марін іншуренс" (1992) [9], Національний інститут гігієни і безпеки праці США [1] та інші).

За концепцією Г. Сельє, одна з головних функцій психіки - це урівноваження діяльності організму в постійно мінливих умовах зовнішнього середовища. Г. Сельє виділяє три основні стадії розвитку стресу: перша стадія - аларм-стадія, або стадія тривоги; друга стадія - стадія резистентності, або опору; третя стадія стадія виснаження. На його думку, ці три фази загального адаптаційного синдрому нагадують стадії людського життя: дитинство (з властивою цьому віку низькою опірністю і надмірними реакціями на подразники), зрілість (коли відбувається адаптація до найчастіших впливів і збільшується опірність) і старість (з незворотною втратою опірності та поступовим старінням), що закінчується смертю.

Сельє виділяє два види стресу - еустрес і дистрес. Дистрес завжди неприємний, він пов'язаний зі шкідливим стресом. Еустрес поєднується з бажаним ефектом активізуються психічні процеси, емоції мають показовий характер. Один і той самий стресор може спричиняти неоднакові наслідки у різних людей. Сельє пов'язує це з "чинниками обумовлення", які вибірково підсилюють або гальмують той чи інший прояв стресу. "Обумовлювання" може бути внутрішнім (генетична схильність, вік, стать) і зовнішнім (прийом всередину гормонів, лікарських препаратів, дієта). Відіграє роль і реактивність організму, що змінюється залежно від внутрішніх і зовнішніх умов. Одна і та сама ситуація може спричиняти тривогу в однієї людини, фрустрацію - у другої та конфлікт - у третьої. Окрім цього, якщо захисна реакція тривала й виснажує ресурси фізіологічних механізмів, то вона переходить у стан хворобливої адаптації $[11,13]$. Отже, Г. Сельє акцентував увагу на фізіологічній стороні реакції організму і цим самим ігнорував роль психологічних процесів, психологічного впливу стресора на особистість.

Реакція людини-оператора на екстремальні ситуації. Поведінку людини-оператора під час дії подразнювального чиннику можна подати 3 використанням прямокутного імпульсу 3 амплітудою $H$, яка виражає величину перенапруження оператора, що виникло в момент часу $t_{i}$, усвідомлення $\dddot{11}$ оператором, тривалістю $\Delta t=t_{i+1}-t_{i}$ прийняття рішення, та спадної нелінійної функції $H^{*}=H \times \phi(t)$, визначеної на такому інтервалі $t \in\left[t_{i+1}+1, T\right]$. Вона характеризує включення і дію компенсаторних механізмів повернення до нормального функціонального стану, причому в момент часу $t_{i+1}, \phi\left(t_{i+1}\right)=H$ і при $t \rightarrow \infty, 1 \geq \phi(t) \geq 0$. Тобто екстремальна ситуація характеризується величиною нервово-психічного перенапруження людини-оператора, яке ця ситуація спричинила.

Упродовж часу $\Delta t=t_{i+1}-t_{i}$ людина-оператор опрацьовує та аналізує деталі надзвичайної ситуації, відбувається усвідомлення ii деталей, промальовування подій у свідомості та генерування альтернативних до основного рішень. Також на цьому етапі формуються критерії оцінювання, аналізу зі своєї сторони найбільш адекватного в цій ситуації рішення. Усвідомлення можливих наслідків, породжених певним рішенням, спри- 
чиняють ще більше нервове напруження на оператора, створюючи додатковий стрес та тиск на його свідомість. Остаточним вважається кінцеве рішення, прийняте в момент часу $t_{i+1}$.

Функція $\phi(t)$ характеризує спад перенапруження після прийняття у цій ситуації рішення. Проте кожна екстремальна ситуація зумовлює: переживання, побоювання, емоційні вираження, реакції на них, процеси аналізу та вибору рішень (рис. 1).

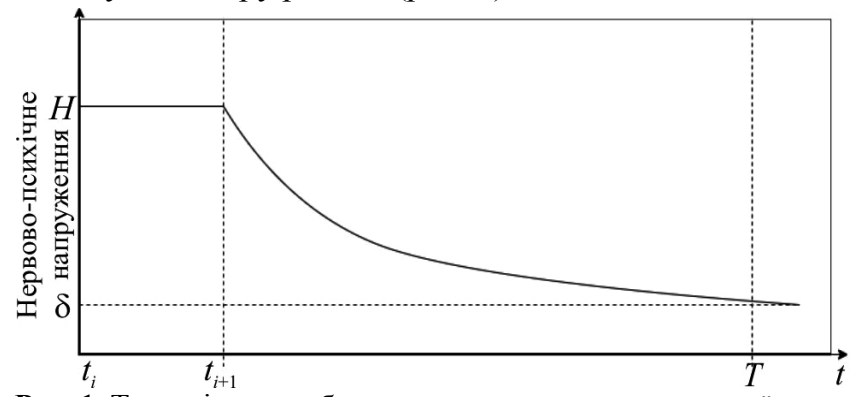

Рис. 1. Тривалість перебування та виходу з екстремальної ситуації: $\delta$ - остаточне перенапруження; $t_{i}-$ момент часу; $t_{i+1}-$ наступний момент часу; $H$ - амплітуда; $T$ - кінцевий момент часу

Отже, залежно від розташування $t_{i+1} \mathrm{i}$ характеру екстремальної ситуації, яка позначилася на емоційному стані та пам'яті вражень і переживань оператора в момент часу $T$, значення добутку $H \times \phi(T)$ переважно дорівнює деякому остаточному перенапруженню $\delta$, як це показано на рис. 1. Ця модель визначає тривалість перебування та виходу з екстремальної ситуації оператора на основі методу декомпозиції складного імпульсу, де тривалість визначається часом перебування оператора в розглядуваній ситуації.

Вплив накопичення остаточних перенапружень. Відомо [12], що у процесі виконання роботи кожна людина переживає різні функціональні стани, які зумовлюють відповідні рівні іiі працездатності. Відповідно, можна виділити чотири фази працездатності: входження у роботу, відносно стійка працездатність, нестійка працездатність, прогресивне зростання втоми і зниження працездатності.

Фаза входження у роботу - це час, протягом якого людина адаптується до майбутніх умов праці. Вона може тривати від кількох секунд до десятків хвилин.

Фаза відносно стійкої працездатності характеризується найвищою якістю праці, при цьому рівні функціонування фізіологічних систем організму мають бути оптимальними. Тривалість цього періоду становить від 3 до 4 год, залежно від інтенсивності роботи. Великий вплив на процес стійкої працездатності мають емоції. Так, негативні (це можуть бути поганий настрій, страх, невпевненість) знижують працездатність, а позитивні (впевненість, спокій, почуття задоволення) значно продовжують цю фазу. До чинників, які можуть продовжити період відносно стійкої працездатності, можна віднести: оптимальний рівень напруження психофізіологічних функцій; комфортні умови праці; правильне поєднання режимів праці та відпочинку; емоційне розвантаження; використання тонізуючих напоїв (кава, чай) або фармакологічних засобів.

Фаза нестійкої працездатності - це початок розвитку втоми. Рівень працездатності в цій фазі починає змінюватись. Якщо розглядати розумову діяльність, то ця фаза може настати через 1,5-2,0 год роботи.
Фаза прогресивного наростання втоми і зниження працездатності- характеризується чітко вираженим зниженням якості роботи внаслідок подальшого погіршення функціонального стану людини. Ї̈і ще називають фазою втоми. При цьому до об'єктивних показників втоми можна віднести зміну частоти пульсу, дихання, зорової та слухової чутливості. Під впливом втоми погіршується сприйняття, послаблюється пам'ять і знижується продуктивність.

Проте, варто зауважити, що тривалість кожної з цих фаз залежить від рівня підготовки людини до роботи та від характеру самої роботи. Щоб оцінити працездатність, можна застосувати такі групи показників: виробничі (продуктивність праці, трудомісткість роботи, якість роботи), фізіологічні (величина енергозатрат; частота пульсу, ударний і хвилинний об'єм крові; м'язова сила; м'язова витривалість; час сенсомоторних реакцій; частота дихання і т.ін.) та психологічні (увага, мислення, пам'ять, сприймання, емоційно-вольове напруження).

Тривале перенапруження призводить до розвитку посттравматичного стресового розладу - тривоги, роздратованості, нервозності, послаблення зосередженості уваги або непродуктивність у роботі, нестача почуттів і нездатність взаємодіяти з іншими людьми. Найбільш істотна риса посттравматичного стресового розладу - багатократне повторне переживання первинної травми у яскравих спогадах або нічних кошмарах. Посттравматичний стресовий розлад може виникати після травми або бути відставленим у часі, мати тимчасовий характер або постійний вияв.

Дослідження реакції оператора у стресових ситуаціях. Будь-яка несподіванка, що порушує звичний перебіг життя, може стати причиною стресу або стресором. При цьому не мають значення зміст самої ситуації

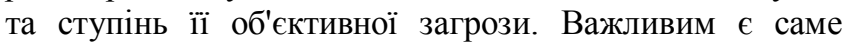
суб'єктивне ставлення до неї. Тому певну ситуацію одні можуть сприймати як стресову, а інші - без жодної реакції. Матимуть значення внутрішні психологічні особливості людини. Отже, виникає потреба у кількісній оцінці стресу, тобто надати стресу статусу вимірюваної величини (поза численними якісними описами його форм, типів тощо). Застосування такої методології очевидно дасть змогу прогнозувати очікувані ризики шкоди, передусім для організму, та планувати відповідні профілактичні заходи. При цьому, як видно 3 дослідження, методи замірів окремих стресорів (виробничих чинників: шум, вібрація, іонізація, пилове навантаження, мікроклімат й інші) існують і показують на практиці хороші результати.

Виробничі показники характеризують ефективність роботи і опосередковано - рівень працездатності. Продуктивність праці починає знижуватися внаслідок значного розвитку втоми, оскільки на початкових іiі стадіях відбувається компенсація завдяки резервним можливостям організму.

Нехай $z$ - найменше значення рівня перенапруженого стану. Імовірність того, що в деякий момент часу $T<t$ сума остаточних перенапружень досягне рівня перенапруженого стану, $z$ може бути визначена з розподілу $F(W)=P\{W(t)<z\}, t_{i}<z$. Функціональний стан, в якому перебуває людина-оператор протягом своєї діяльності на робочому місці в межах трудової зміни, не за- 
лишається постійним і його зміну формально можна представити моделлю часового ряду.

За відсутності будь-яких стресових ситуацій тренд функціонального стану людини-оператора відповідатиме тренду часового ряду $y_{1}(t)$. Проте, за умов створення додаткових навантажень та виникнення непередбачуваних ситуацій, тренд буде $-y_{2}(t)$ (рис. 2). Згідно з методом протиставлення, значення, які утворюють тренд $y_{2}(t)$, будуть порівняні 3 відповідною еталонною величиною, яка містить еталонне значення кожного показника. Аналізуючи отримані дані протягом робочої зміни оператора, можна визначити максимальні значення кожного $з$ показників стану організму та сформувати докладний звіт реакції показників на певні подразники.

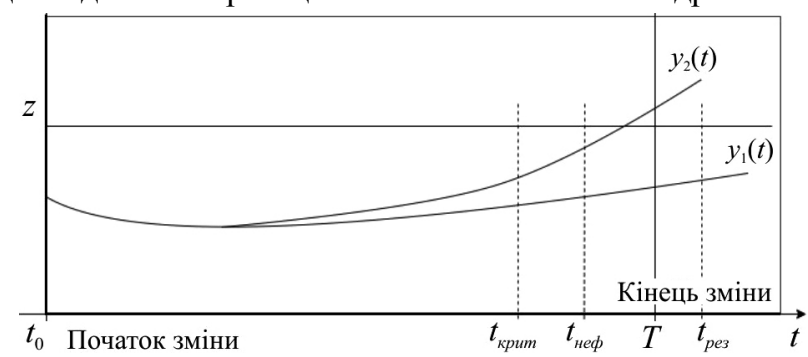

Рис. 2. Відмінність у часових рядах, зумовлена остаточним перенапруженням: $t_{0}-$ початковий момент часу; $t_{\text {крит }}-$ критичний момент часу; $t_{\text {неф }}-$ неформальний момент часу; $t_{p e з}-$ результативний момент часу; $y_{1}(t)$ - тренд при відсугності стресових ситуації; $y_{2}(t)$ - тренд наявності стресових ситуації; $T$ - кінцевий момент часу; $z$ - найменше значення рівня перенапруженого стану

Визначити тривалість ефективної роботи людиниоператора можна за допомогою дослідження реакції останнього в умовах стресу. Для цього використали звичайну форму з основними параметрами, характеристики яких повинна досліджувати людина-оператор (рис. $3, a)$.

a)
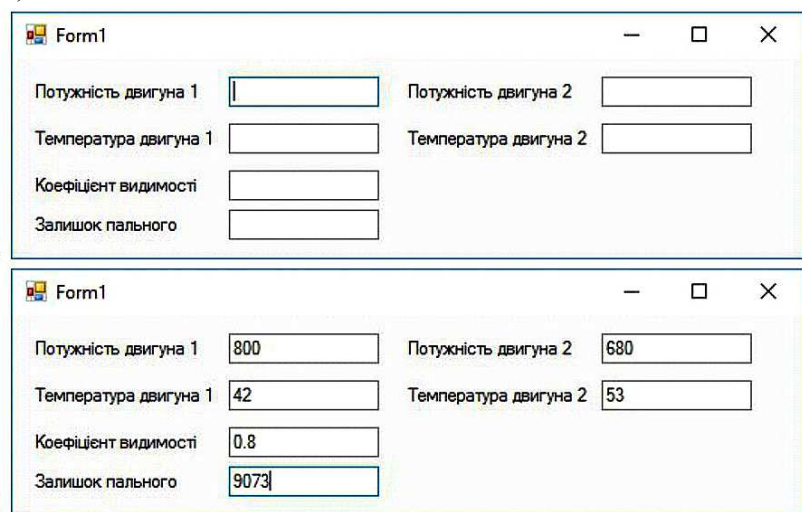

б)

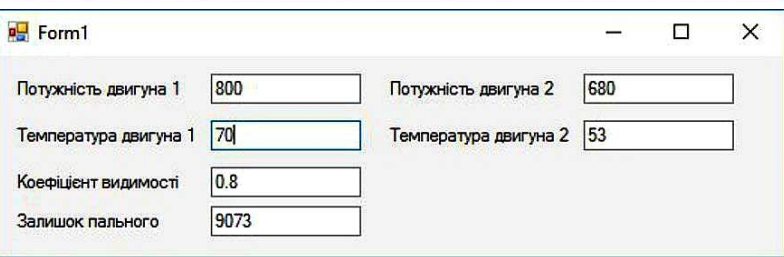

в)

\begin{tabular}{|c|c|c|c|c|}
\hline 㫛 Form1 & & & - & $\square$ \\
\hline Погужність двигуна 1 & 420 & Потужність двигуна 2 & 680 & \\
\hline Температура двигуна 1 & 45 & Температура двигуна 2 & 80 & \\
\hline Коефіціент видимості & 0.4 & & & \\
\hline Залишок пального & 9073 & & & \\
\hline
\end{tabular}

Рис. 3. Форма основних параметрів (a); нормальні характеристики параметрів (б); різке збільшення температури двигуна 1 (в); різка зміна декількох параметрів (2)
Нехай нормальні характеристики параметрів подано на рис. 3,б. Для початку варто дослідити реакцію людини-оператора на різке збільшення числової характеристики одного $з$ параметрів. Нехай у випадковий момент часу відбудеться різке збільшення температури двигуна 1 вище від норми, як показано на рис. 3,6.

Реакція людини-оператора на початку зміни буде блискавичною, він швидко встановить цю температуру в межі норми. Згодом відбудеться різкий стрибок температури двигуна 2 вище від норми (рис. 3,2). Водночас, коефіцієнт видимості зменшиться до критичного показника. Дії людини-оператора ближче до кінця робочої зміни через попередні стреси будуть не такими злагодженими, оскільки на іiі реакцію впливатимуть попередньо перенесені стреси.

Після виконання цього експерименту було проаналізовано та змодельовано рівень стресу трьох людей під дією стресових чинників протягом робочої зміни у вигляді часових рядів.

Подання на рис. 4 моделює перенапруження трьох людей у вигляді часових рядів $y_{1}(t), y_{2}(t), y_{3}(t)$ відповідно. 3 цього дослідження можна зробити висновок, що на різних людей по-різному впливають подразники під час робочої зміни. Унаслідок на всьому штаті людей можна визначити середній показник стійкості працівника. Цей підхід буде досить дієвий під час набору кадрів, оскільки стресостійкість людей в деяких професіях відіграє значну роль в ефективності виконання поставлених завдань та дасть змогу визначати людей, неспроможних працювати в певних умовах вже на початкових етапах роботи.

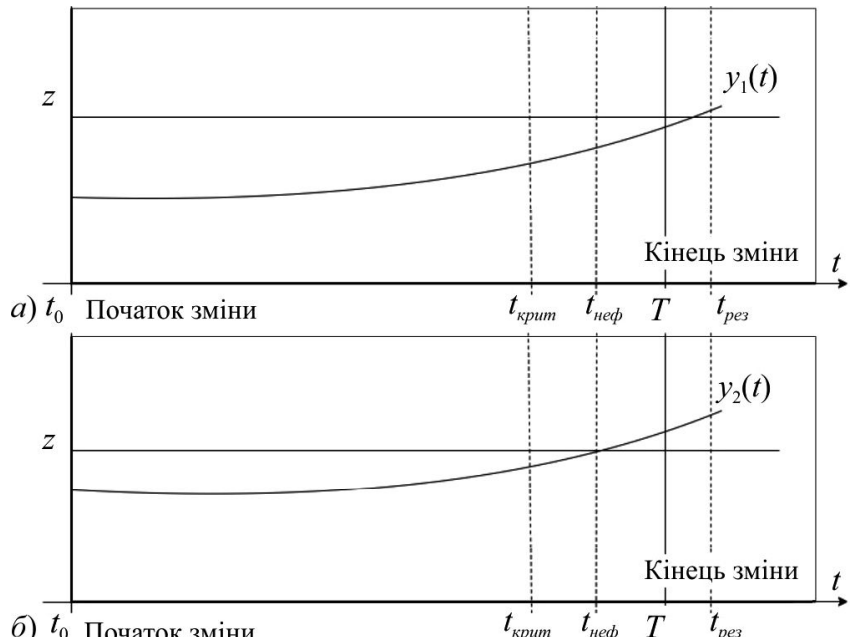

б) $t_{0}$ Початок зміни $\quad t_{\text {криm }} t_{\text {неф }} \quad T \quad t_{\text {pes }}$

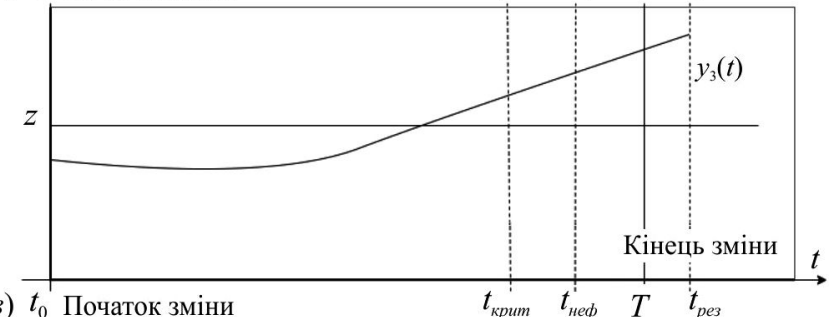

Рис. 4. Змодельоване перенапруження людини у вигляді часових рядів: $y_{1}(t), y_{2}(t), y_{3}(t)$ - тренди перенапружень операторів відповідно 1, 2 і 3 (решта позначень див. рис. 2)

Аналізуючи отримані результати, можна простежити істотну оптимізацію роботи порівняно 3 наявним аналогом "Вектор 01.1", а саме: спрощення роботи з даними - усунення необхідності використання додаткового продукту та конвертації даних, опрацювання та пе- 
регляд даних у реальному часі; аналіз перепадів показників стану людини-оператора та їх відношення до відповідних подразників. Біомедична система МІC - ДЕС здійснює передачу даних за допомогою каналів зв'язку 3 відповідним інтерфейсом, чого поки немає у відповідній системі, проте не моделює поведінки людини-оператора, а своєю роботою більшою мірою призначена для аналізу фізіологічної і психічної складових кваліфікованим працівником.

На основі аналізу явища стресу [10]: його різновидів, причин виникнення, наслідків впливу на людину, напрямів вивчення та аналізу показників стресостійкості можна зробити такі висновки:

- сучасний світ потребує формування та інвестування окремої галузі "стресологія" як системи дослідження та управління стресами на виробництві;

- як уніфіковані складові можна вважати такі концептуальні положення:

- у всіх випадках стрес - це реакція людини на ситуацію або подразник, що вже стався; це відповідь на реальний вплив стресора;

- залежно від типу зазначених стресогенних ситуацій виниклі стреси потребують спеціальних механізмів управління: під час очікування негативу (стрес очікуваний) застосовувати запобіжні заходи, профілактичні дії;

• можливо виділити два методологічних напрями управління стресом:

1) 3 позицій стійкості працівника: психічної (первинної) та фізіологічної (вторинної) як стресорних реакцій (емоційні, поведінкові, фізіологічні), зокрема, як адаптації до стресогенної ситуації, зміни стану здоров'я та лікування від стресу. Це відноситься до реактивного методу, що $є$ найбільш опрацьованим. Наприклад, тільки в емоційному стресі вирізняється три стадії: тривога, резистентність, виснаження;

2) 3 позиції вирішення стресової проблеми через профілактику стресогенних ситуацій.

Висновки. На основі виконаного аналізу реакції людини в умовах стресової ситуації запропоновано сформувати окрему галузь "стресологію" як систему дослідження та управління стресами на виробництві. Встановлено, що на різних людей по-різному впливають подразники під час робочої зміни, оскільки не менш важливу роль відіграють зовнішні джерела стресу, тобто ті, що формуються поза межами виробництва та суб'єктивне ставлення працівника до ситуації загалом. $\mathrm{У}$ роботі показано, що на всьому штаті людей можна визначити середній показник стійкості працівника. Цей підхід буде досить дієвий під час набору кадрів, оскільки дасть змогу визначати людей, неспроможних працювати в певних стресових умовах вже на початкових етапах роботи. Розроблено програмний продукт для спрощення застосування цього методу відбору. В іншому випадку, можна сформувати очікуваний показник ефективності роботи працівника.

\section{References}

1. Cooper, C., \& Marshall, I. (1976). Occupational sources of stress. Occup. Psychol., 49, 11-28.

2. Entciklopediia po bezopasnosti i gigiene truda. (2001). (4th ed.). (Vol. 2). Moscow: Mintruda, 925 p. [In Russian].

3. Galinsky, E., Bond, I. T., \& Friedman, D. E. (1993). The National Stady of the Changing Workforse. New-York: Families and Work Institute.

4. Honchar, M. F., \& Bilyk, Yu. V. (2017). Osoblyvosti upravlinnia u stresovykh sytuatsiiakh. Stres-menedzhment na pidpryiemstvi. (Ser. Economical). Scientific Bulletin of UNFU, 27(2), 94-97. https://doi.org/10.15421/40270220

5. Honchar, M. F., \& Kuzmin, O. Ye. (2017). Stres-menedzhment u systemi upravlinnia pidpryiemstvom. Biznes Inform, 5, 233-239. [In Ukrainian].

6. Houtman, I., \& Rompler, M. (1995). Risk factor and occupational risk groups for work stress in the Netherlands. Washington: American phychological Association.

7. Kagan, A., \& Levi, I. (1971). Adaptation of the psychosocial environment to mans abilities and needs. New-York: Oxford University Press.

8. Matteson, M. T., \& Ivancevich, I. M. (1987). Controling Work Stress. San Francisco: Jossey-Bass.

9. Roy, D. I. (1995). Nayoffs down, but will continue despite surging economy, analysts say. BNA Labour Daily.

10. Sele, G. (1976). Stress bez distressa. Moscow: Progress, 126 p. [In Russian].

11. Sikora, L. S., Tkachuk, R. L., Manyshyn, I. R., \& Lysa, N. K. (2007). Kohnityvna psykholohiia intelektu dlia syntezu testiv vidboru operatyvnoho personalu ASU. ZNP, Instytut problem modeliuvannia v enerhetytsi, 42, 161-163. [In Ukrainian].

12. Torianyk, Zh. I., Pelepetskyi, V. I., \& Nedozhdii, V. V. (2018). Stres-testuvannia yak suchasnyi instrument ryzyk-menedzhmentu. Infrastruktura rynku, 25, 771-775. [In Ukrainian].

13. Yakymovych, O. N., \& Boiko, N. I. (2018). Rol kohnityvnoi intehratsii v ekspertnykh systemakh navchannia. Suchasni informatsiini tekhnolohii ta innovatsiini metodyky navchannia $v$ pidhotovtsi fakhivtsiv: metodolohiia, teoriia, dosvid, problemy, 52, 161164. [In Ukrainian].

L. I. Mochurad, N. I. Boyko, M. V. Yatskiv

Lviv Polytechnic National University, Lviv, Ukraine

\section{MODELLING OF HUMAN STRESS SITUATION IN AUTOMATED CONTROL SYSTEMS OF TECHNOLOGICAL PROCESSES}

The results of the review of various researchers of the analysis of the causes and effects on the human body and behavior in stress during the management of technological processes are presented. The relevance of the issue highlighted in this article is due to the fact that the modern person is influenced by a large number of stressors. Daily stresses make a person overcome a variety of difficult life circumstances. As a result, the person uses a special type of behavior - overcoming, which is aimed at overcoming life difficulties of different levels. The article substantiates the relevance of studying the problem of overcoming behavior of specialists associated with technological processes. Particular attention is to be payed to the resources that help productively deal with stress and maintain the psycho-emotional health of the individual. Issues identified that there still is a need for further study and resolution. That is the need to design a separate branch of "stressology" as a holistic system for the study and management of stress. On the basis of these observations, the probable model of duration of stay and exit of a person from an extreme situation is investigated. The correlation between levels of performance and psychological and emotional state of a person was examined. Investigation of the manifestation of stress as a non-specific response of the body in response to an unexpected and tense situation is deepened. The source of stress is found to be both external and internal. The focus is made on the consequences, causes and stages of the deployment of stress, as well as the factors that contribute to overcoming it. On the basis of the study, a comparative characteristic of tendencies of person's stress re- 
sistance to external stimuli in the conditions of endurance was performed. The results of the study of stress-coping behavior regarding different types of stress are given, the main attention is focused on industrial stresses. People's reactions are divided into two major groups: physiological and psychological. The paper proposes an approach that will be quite effective during the recruitment process, since the stress resistance of people in some professions plays a significant role in the effectiveness of fulfilling tasks and will help to identify people who are unable to work in certain conditions already at the initial stages of work. The prospect of further research is to determine the main factors that influence the effectiveness of stress-coping behavior of a person, depending on the degree of exercise.

Keywords: stressor; stress; stress reactions; stressful changes. 